\title{
7
}

\section{Urban Gardening and Rural-Urban Supply Chains: Reassessing Images of the Urban and the Rural in Northern Vietnam}

\section{Sandra Kurfürst}

\section{Introduction}

This chapter examines the sites of production of what consumers in Vietnam perceive to be rau sach, rau an tòn (clean and safe vegetables). First, it focuses on the spaces and practices of gardening in the city. Second, it examines the practices and images that constitute and underlie the rural as a signifier of fresh and clean food.

The twenty-first century has been termed the "Asian urban century" with half of the urban world population living in Asia (UN-Habitat 2012, p. 28). Roy (2014, p. 14) comprehends the Asian urban century as the "historical conjuncture", at which the urban becomes a matter of government. Urbanism then is "produced through the practice of statecraft and the apparatus of planning" (Roy 2014, p. 14).

After extensive phases of zero-urban growth and de-urbanization during the Indochina Wars, Vietnam is now on the threshold of becoming

S. Kurfürst $(\bowtie)$

Global South Studies Centre (GSSC), University of Cologne,

Cologne, Germany

e-mail: s.kurfuerst@uni-koeln.de 
an urbanized society. In 2016, 34 per cent of the population was living in urban areas with 1.2 million people moving to the city each year, as compared to 1960 , when only 15 per cent of the population was residing in cities (Thanh Nien News 2016; World Bank 2018). Recognizing the city's capacity as a hub of economic growth and remedy for economic crisis (UN-Habitat 2012), the development of "modern and civilized" cities (đô thi hiện dại văn minh) ${ }^{1}$ throughout the country has become a state priority. Historically, the royal city in Northern Vietnam was defined by the confluence of officialdom and sacrality. In the eleventh century, Hanoi was founded as a sacred city - its centre being defined by the location of the royal palace and temple in the rectangular and enclosed space of the citadel (Kurfürst 2012a, p. 35). By contrast, the countryside in Vietnam is associated with the village that is regarded as the cradle of Vietnamese civilization. Nguyen Tu Chi (1993, p. 47) defines the village in Northern Vietnam as the "basic cell of Vietnamese society". Northern Vietnamese village communities have evolved as tropes of autonomy from state power and independence from colonial domination, both exerted from the city (Marr 2004; Phan Huy Le 2006). Today the urban is still considered the locus of political power and a hub of modernization. While rural areas are valued for their productivity, nurturing the nation, rural spaces and residents have also increasingly come to be designated as backward (To Xuan Phuc 2012; Salemink 2018). Harms (2011b, p. 457) concludes that the rural is addressed with "both reverence and paternalitistic subordination to the urban centre".

Although the division between the city and the countryside cannot be properly physically located, the binary categories of the urban and the rural still inform the ways that people imagine space (Harms 2011a, p. 84). Accordingly, designations of the rural and the urban are crucial to both the politics of place and belonging and the politics of space and rent-seeking. For those living in the city and the countryside, the urban and the rural are important markers of identity and belonging. By contrast, the state holds the classificatory authority over these spaces. Designating a space as rural or urban ultimately alters and determines its use function and economic value.

Focusing on the sites of production of clean and safe vegetables, that is, urban gardens and rural areas, the paper argues that while the 
boundaries between the rural and the urban are constantly crossed in everyday practice, they are maintained as socially constructed—though often ambivalent-binaries.

\section{Urban Gardening}

Urban gardening can be observed in cities around the globe (Follmann and Viehoff 2015). It comprises diverse forms of small-scale agricultural production in the city, conducted in public space, private gardens or on rooftops. Some municipalities even explicitly promote urban gardening in the form of municipal projects, such as the "eatable city". ${ }^{2}$ However, the spaces and their meanings vary widely according to the socioeconomic and political context in which they are based. According to Lefebvre (1991) every society has its own space. Space is socially produced and thus relations of production are manifested in space (Lefebvre 1991, pp. 33, 129). In much of the literature, urban gardening is conceptualized as a political act, particularly a critique of the neoliberal system (Certomà 2011; Schmelzkopf 2002; Staeheli et al. 2002). For example, the term "guerrilla gardening" refers to individuals' or groups' appropriation of private or public spaces without the landowner's permission by planting flora (Flores 2006). Accordingly, guerilla gardening has come to denote a political practice in public space (Adams and Hardman 2014). The formation of collective gardens, such as the community gardens in Great Britain and Australia or Prinzessinnengärten ${ }^{3}$ in Berlin further hint at urbanites' interest in the origin of agricultural products and their distrust in anonymous commodity chains (Bendt et al. 2013; Evers and Hodgson 2011; Witheridge and Morris 2016; Participant observation Berlin 2015). Moreover, these social gardens do have a communicative function as well. They serve as a basis of social cohesion in an estranged urban environment (Firth et al. 2011). What initially started out as a temporary occupation of highly valued fallow urban land is frequently sought to be transformed into sustainable green spaces (Follmann and Viehoff 2015). Citizens negotiate land tenure with the municipality or the private owner of the land lot to maintain the garden. That is how individuals and collectives transform urban space through their gardening 
activities into urban commons. In fact, the creation of gardens on urban land counters the very linkage between urbanization and capitalism. According to David Harvey (2012, p. 42) urbanization takes over a particular role "in the dynamics of capital accumulation because of the long working periods and turnover times and the long lifetimes of most investments in the built environment". In other words, urban gardens occupy land that could otherwise be used for real estate development, which would contribute to private rent-seeking.

The particular discussion of urban gardening as an expression of the right to the city is very much informed by research on cities of the Global North (Certomà and Tornaghi 2015). On the contrary, small-scale agricultural production or urban farming in the cities of the Global South has long been discussed in the context of poverty alleviation, urban informality and thence with a focus on the urban poor (Bakker et al. 2000; Ngome and Foeken 2012; Simiyu and Foeken 2014). Overcoming the developed versus developmental divide in urban and development studies (Robinson 2006; Parnell and Robinson 2013), this chapter alludes to the cultural history of urban gardens in Hanoi. In effect, it suggests, for private gardens in particular, a transformation from a sacred function to a utilitarian one. What is more, urban gardening in Hanoi, like in many Northern cities, can, at times, be an expression of the right to the city, too. By occupying public spaces for gardening, urbanites actively shape the urban landscape, challenging the state's planning apparatus.

Actors in urban gardening are frequently driven by their concern for food safety. Interviewees, all of them belonging to the urban middle class, ${ }^{4}$ mentioned a longing for clean and safe vegetables, as well as the relaxation achieved through gardening, as major motives for growing their own produce. In particular, families with small children are concerned about the safety of the produce they use to cook meals for their children (see Faltmann, this volume). This is particularly the case for the ingredients of the rice soup cháo, such as greens, mushrooms and soy sprouts (Le Huu Viet and Tra Giang 2014). The aspect of care for the family appears to be crucial in the decision to grow fresh produce at home. Additionally, interviewees try to ensure food safety by drawing on their urban-rural ties. This chapter links the empirical findings on urban gardening and the rural-urban supply chains to the broader discussion on 
the rural-urban dichotomy in Vietnam (Drummond 2003; Fuhrmann 2017; Gillen 2016; Harms 2011a, b; Kurfürst 2012a; Labbé 2016). It concludes that the socially constructed oppositions of the rural and the urban not only inform the way people imagine (urban) space (Gillen 2016; Harms 2011a), but also what they imagine to be clean and safe vegetables.

The data presented in this chapter were gathered through qualitative methods comprising semi-structured and narrative interviews with practitioners of urban gardening, site visits to gardens, as well as expert interviews with botanists, agronomists, historians and social anthropologists, conducted between September 2014 and October 2015 in Hanoi. The selection of the gardens and interviewees was based on snowball sampling. Since the concern for food safety is omnipresent, I was directed to different interview partners by my colleagues and friends in Hanoi, once I had introduced my research topic of clean and safe vegetables. The names of the interviewees have been altered in order to make them anonymous. In addition, content analysis of Vietnamese language newspapers such as Tiền Phong and online fora was conducted. To achieve comparisons with urban gardening in cities of the Global North, additional site visits were conducted to gardens in Berlin. In April 2015, I visited the aforementioned public-access community garden Prinzessinengärten as well as the Tempelhofer Feld. The latter is a former airfield that primarily served as a US military base until German reunification in 1990. In 2014, it was decided by referendum to transform the airfield into an open green space, with some of the area allotted to urban gardening (Dannenberg and Follmann 2015).

\section{Agricultural Production in the City: Continuity and Change}

The cultivation of vegetables around the house, in home gardens or on the sidewalks is nothing new, neither in Ho Chi Minh City nor in Hanoi (Le Huu Viet and Tra Giang 2014). The continuity of the rural within the urban-comprising both spaces and practices-is a particularly important feature of Hanoi's urbanism. Since the foundation of the 
capital Thăng Long in the eleventh century, agricultural villages have been central to the city's food supply system. In particular the 13 farms (thâp tam trai) located west of the royal citadel-in today's Ba Đinh District - provided the royal city with agricultural products such as vegetables, flowers and medicinal herbs (Kurfürst 2012a). In addition, villages north of the royal city, located on the stretch of land surrounded by West Lake and the Red River used to produce speciality plants, such as đào and quất trees, the traditional Vietnamese Lunar New Year tree, as well as rice and vegetables for the city (Leaf et al. 1999; Leaf 2002).

Only through the urban sprawl and the densification of the inner city-particularly during the 1990s - were these former spaces of agricultural production turned into land for construction (see Gorman, this volume). While the cultivation of speciality plants was moved beyond the dike to the fertile grounds on the banks of the Red River (Leaf et al. 1999), food production for the city was confined to the urban hinterland. Yet, with the growing gardening activities in the inner city, practices associated with rural areas, such as agricultural production or animal breeding seem to re-enter the city.

The chapter focuses on the gardening activities in two districts that used to be sites of agricultural production: first, the area located around West Lake, in what is nowadays Tây Hồ District; and, second, the area known as Bắc Từ Liêm, which only became a part of Hanoi through the adjustment of the city's administrative boundaries in $2008 .^{5}$

\section{Gardening in Private Space}

Gardening in private space, on a land lot belonging to the household, has a long tradition in Vietnam. In rural areas, families used to have a private garden adjacent to their house. The garden made up one-third of the land lot and was used for growing vegetables. A further site of cultivation was the house's courtyard, in which ornamental trees were grown (Expert Interview with Social Anthropologist, Hanoi October 2015; Nguyen Khac Tung 1993). While the garden was a space of production, the courtyard referred to the realm of aesthetics. This functional division is also represented linguistically. While agricultural production translates into 
trồng rau, literally meaning growing vegetables, the art of growing bonsai trees is called chơ i cây cánh, translating into "playing bonsais". The semantics reveal a differentiation between an everyday necessity, namely the cultivation of vegetables, and the joyous endeavour of planting ornamental trees.

With the move to the city, house owners often maintained the planting of ornamental trees. In Hanoi's narrow tube houses, bonsai trees are grown on little balconies or on the rooftop.

Home gardens were also promoted by the socialist state from the $1960 \mathrm{~s}$ onwards in order to produce medicinal herbs, which are required to produce Southern medicine (thuốc Nam). Southern medicine corresponds to Traditional Chinese Medicine in the way that it is based on elements extracted from the local flora and fauna. ${ }^{6}$ In fact, the Vietnamese state sought to promote people's self-sufficiency, particularly in rural areas, by encouraging them to grow medicinal plants for the treatment of the most common ailments such as headache and diarrhoea (Wahlberg 2012a, pp. 216-217). That is why today, still, many Vietnamese are familiar with the domestic production of medicinal herbs.

The following examples shed light on the spaces, plants and motivations for gardening in private. When speaking of gardening in private, this chapter refers to the private space of the home. In Vietnam, an individual or private company can acquire land-use rights for a particular lot. According to the Vietnamese Land Law all land belongs to the entire population, but the right to management is held by the state. The state issues land-use rights to individuals, thus allowing them to use the land (Anon. 2001, p. 7; Nguyen Van Suu 2004, p. 270). Such land-use rights also determine the specific use of a lot. That is why only few private gardens do still exist in the inner-city districts as most of the land has been transformed from land for agricultural production into construction land. Therefore the following examples focus on private rooftop gardens. The first rooftop garden is located in the aforementioned new residential area of Bắc Từ Liêm. The second rooftop garden is located right in the city centre, close to Hanoi's Ancient Quarter.

Bắc Từ Liêm is a new residential area in the West of Hanoi with spacious detached houses and broad sidewalks. The area was only developed ten years ago on former paddy fields. Mai and her husband live together 
with their two sons in a four-storey house. On each floor is a room with a small balcony facing the street. On the balconies, the family cultivates different kinds of foliage plants, mainly ornamental trees. Through a small window in the attic, the family can access the roof. On the rooftop, Mai grows diverse herbs, such as mint. She used to cultivate different kinds of vegetables, but her harvest was destroyed by a rat. That is why she turned to the cultivation of fragrant greens, which, she explains, rats do not like to eat. The mother of two grows her own vegetables because she is concerned about her children's health. Although she has to purchase additional fresh produce from the market, she says "at the market you can never be sure if the vegetables are really clean and where they come from. The sales woman at the market might get it one day from one supplier and the next day from another" (Interview October 2015, translated from Vietnamese).

Urban gardening in Hanoi is also conducted right in the city's historical centre. In Hanoi's central Hoàn Kiếm District is a narrow two-storey house owned by a retired couple. The couple lives on the first and second floors, while the ground floor is occupied by a photo shop. The second floor is divided into an inner space as well as an outer space, featuring the rooftop garden. The inner space houses a big altar with a picture of Buddha in the centre. Outside, the garden comprises a mixture of vegetables, medicinal herbs and ornamental trees. In the middle of the outer space, there is even a small pond. The house owner, named Thắng, explains that his garden is a miniature world, a symbol of love for nature (yêu thiên nhiên) and "longevity"-using the English term (Interview October 2015). Plants, stones and water are arranged according to the principles of feng shui (phòng thiu). Ornamental trees are decorated together with precious stones in the shape of a Buddhist monk, a lingam or a holy animal (con vạt thiêng). Accordingly, the rooftop garden becomes a spatial continuity of the inner sacred space of worship. In between the pots of ornamental trees stand pots and boxes of leafy greens such as lá lôt (piper lolot), rau răm (known as Vietnamese coriander) and rau xüơng sông (blumea lanceolaria). ${ }^{7}$ Thắng explains that he likes to garden and wants to have access to clean vegetables. Apart from vegetables, he cultivates different kinds of medicinal herbs, which are essential to the production of Southern medicine. Thắng cultivates herbal plants for the 
treatment of low blood pressure and arthrosis. In addition to curing diseases, some medicinal plants also have ritual functions. He gives the example of the tree cây dây mó qua (Dischidia major) that is used to prevent bad spirits from entering the house. Consequently, Thắng's rooftop garden unites the realm of profane domestic production with the realm of the sacred, in the form of holy trees and stones, as well as medicinal plants.

\section{Gardening in Public Space}

The occupation of public space by individuals for private activities is a crucial feature of Hanoi's urbanism. Drummond (2000, p. 2377) refers to the blurring of private and public in Vietnam as "inside out" and "outside in". The former denotes private activities in public space, whereas the latter designates the state's intervention into the private domestic space of the home, such as the state's happy family campaign or policies on family planning. ${ }^{8}$ In particular, the occupation of the sidewalks of the Ancient Quarter for private economic activities, such as petty trade, cafés and restaurants, has been well received in the literature on Hanoi (Anh Dung Ta and Manfredini 2017; Drummond 2000; Koh 2006; Kurfürst 2012b; Thomas 2002). This research shows that the boundaries between private and public space are often fluid and constantly re-negotiated between citizens and local authorities. Such negotiation is made possible through so-called mediation space (Koh 2006, p. 15). Mediation spaces open up when local officials face a moral dilemma. On the one hand, they are part of the local community and want to be compassionate towards their neighbours; on the other hand, they are responsible for implementing the regulations on the use of the sidewalks (Koh 2006, p. 9). While emphasizing the importance of the sidewalks as a space for pedestrians, the municipality of Hanoi nonetheless introduced a regulation in 2008 allowing for the private economic exploitation of the pavements in case a fee is paid to the district (Kurfürst 2012a, p. 104).

The private appropriation of public space can also be observed in the context of urban gardening. In Bắc Từ Liêm, families occupy the wide sidewalks in front of their houses with styrofoam boxes and pots, in 
which they grow vegetables and herbs for private consumption. Asked about why residents are allowed to block the sidewalks, Mai says "It is in front of their house. So they can use it. As long as they [the vegetable boxes] stay in front of their houses no one cares." She goes on to explain that she can tell from the vegetables where families with little children live (Interview October 2015, translated from Vietnamese). First, the quotation shows that it is acceptable to cultivate on the sidewalks, as long as the vegetable boxes are placed in front of the owner's house entrance and do not intrude into the public space in front of the neighbour's house. Second, it points to the existence of mediation space, since local officials seem to tolerate the occupation of the sidewalks for private production and consumption (Fig. 7.1).

In Tây Hồ District, unlike in Bắc Từ Liêm, the sidewalks are rather narrow or non-existent. Instead, residents garden on fallow urban land.

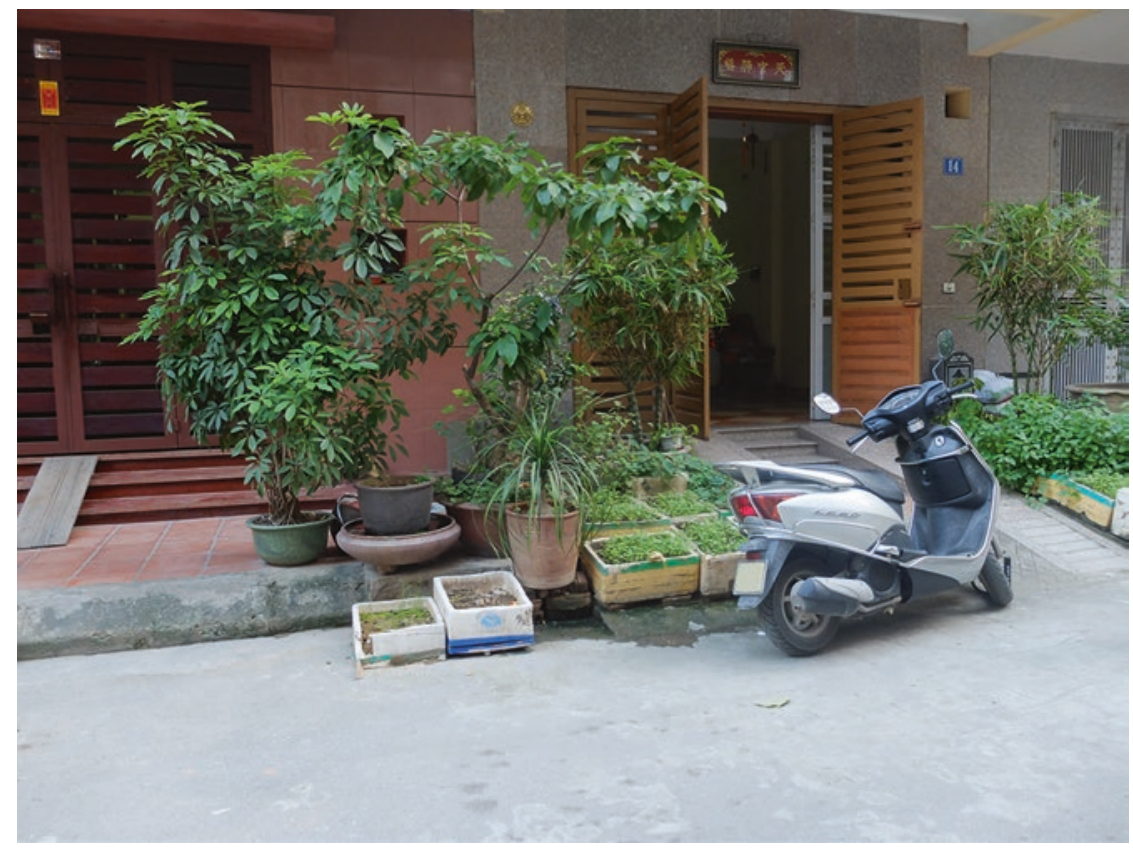

Fig. 7.1 Private appropriation of the sidewalk in Bắc Từ Liêm. (Copyright to image: Sandra Kurfürst) 
For example, in Yên Phụ members of the neighbourhood cultivate vegetable lots on land located in the middle of the street. Although the gardening activity occurs in public space, the lot is not accessible to everyone. Access to the land and the permission to harvest are subject to the social control within the neighbourhood. Only those who cultivate the land are also allowed to harvest (Participant Observation September 2014, October 2015).

The temporary usage of fallow land for gardening is very common in Hanoi and can be frequently encountered in the newly developed residential areas, so-called New Urban Areas of Hanoi (Le Huu Viet and Tra Giang 2014). For land belonging to the municipality, a development plan is often already in existence. Yet, as long as construction work has not started, this kind of interim usage is tolerated by the authorities. In sum, citizens actively shape the urban landscape through their gardening practices. They appropriate urban land dedicated to private rent-seeking and temporarily transform it into an urban common, thereby undermining the state's planning policies and development plans of private investors.

Apart from the sidewalks and fallow urban land, gardening can also be observed in public and particularly sacred institutions, such as the Buddhist pagoda and the communal house. As Hanoi developed from an agglomeration of villages, many urban wards still have their own communal house (dinh), Buddhist pagoda (chùa) and Taoist temple (dèn). Traditionally, the communal house is the residence of the village deity and thence a place where the neighbourhood assembles on occasions such as the deity's birth and death day. Likewise, many Vietnamese visit one of these sacred institutions on the occasion of the first and fifteenth of the lunar month, praying and making offerings for their family's fortune. This chapter presents the gardening activities in Láng Pagoda and Yên Phụ communal house.

Láng Pagoda (Chuà Láng) is located in the same-named street Phố Chùa Láng in Hanoi’s Đống Đa District. The Buddhist pagoda, also known as Pagodes des Dames, was built in the twelfth century under the reign of King Lý Anh Tông. According to members of the pagoda, it is the largest pagoda in Hanoi, occupying 10,000 square metres of land. The whole area surrounding the pagoda used to be famous for the cultivation 
of fresh vegetables and herbs, particularly Vietnamese Basil (rau húng) due to the high-quality soil. A 70-year-old member of the pagoda contemplates "the herbs of Láng Pagoda are a speciality" (Interview October 2015, translated from Vietnamese). They were well known for their fragrance $\left(t h \sigma^{\prime} m\right)$. However, in the scope of urbanization, all the vegetable fields surrounding the pagoda were transformed into land for construction. Today only a few vegetables are still grown on pagoda land, but even here the amount of cultivable land has diminished. The pagoda's allotment garden can be accessed from the main courtyard through a small gate. In between the green small stupas reach into the sky. The land is carefully divided into small lots separated from one another by moats. Each plot is used to cultivate a different kind of vegetable or herb. For example, in October 2015 the pagoda's famous basil as well as cabbage and green onions were grown on the different parcels of land (Fig. 7.2).

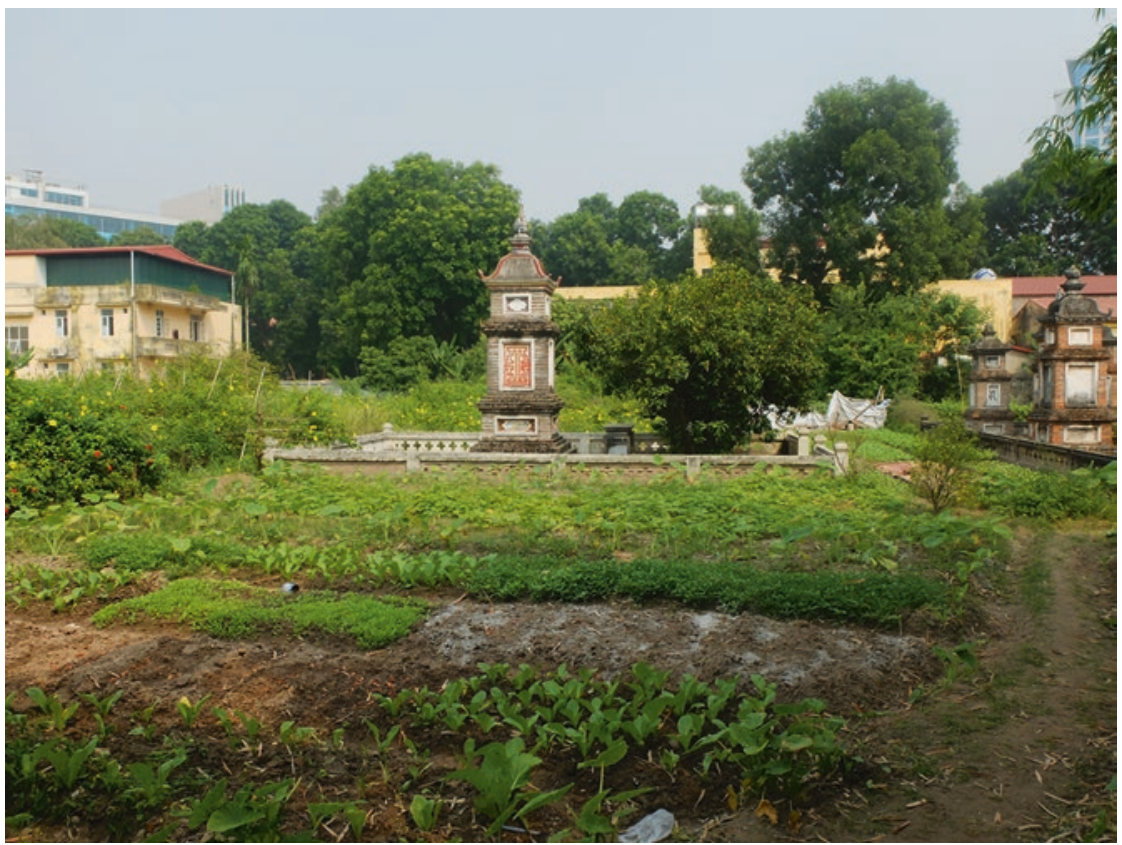

Fig. 7.2 Gardening in Chuà Láng (Láng Pagoda). (Copyright to image: Sandra Kurfürst) 
Given the densification of the area located in between Kim Má, Nguyễn Chí Thanh and Láng Roads, it is actually the institution of the pagoda that guarantees the persistence of gardens. Because the gardens are situated on pagoda land, they cannot be easily transformed into land for construction. Another factor in support of the gardens' persistence is the fact that, during the subsidy era (thời bao cáp), they belonged to the local cooperative (hợp tác xâ). Like China, the Vietnamese government used land collectivisation as a means to achieve the overall aim of the transition to socialism (Nguyen Van Suu 2004). As a consequence, the pagoda land used to be operated by the local cooperative. Tuân, a member of the pagoda, reports that, even today, former members of the cooperative still come to crop (Interview October 2015). During the period of collectivisation, individuals had to participate in the collective production of vegetables. Additionally, families were allowed to use a small lot of land for cropping for the family's own consumption. ${ }^{9}$ Initially acknowledged by the economic reform programme Dổi Mới, this practice of subsistence production still continues on sacred land. In other words, belonging to both the cooperative during the subsidy era and the pagoda community nowadays determine access to the garden, as well as its persistence on pagoda land. Through membership to the pagoda, newcomers to the area like Tuấn, who migrated from his rural home town to Hanoi after de-collectivisation, are also integrated in this very "community of practice" (Lave and Wenger 1991, p. 53).

The members of this community of practice have come to know each other on the basis of face-to-face interaction in the garden and often help each other out: "We exchange. For example if I grow onions, but I would like to have cabbage, I will ask someone who grows cabbage, to exchange with me" (Interview October 2015, translated from Vietnamese). Also the care-taking of the plants is organized among the gardeners. Plants are watered twice a day, in the morning and afternoon, by a person carrying two watering cans on his or her back. While the watering is collectively organized and the gardeners exchange their harvests, they still cultivate for private consumption.

Gardening in sacred space is also conducted in Tây Hồ District. Yên Phụ Ward used to be a village located on the banks of West Lake. Today, some of the old village structures, including the village gate and the 
communal house still exist. Likewise, the name that the residents refer to when speaking of their housing area connotes its past as a village (làng Yên Phụ with làng meaning village). The communal house of the area comprises a garden bordering West Lake. The garden displays both sacred and profane features. Close to the main sanctuary are ceramic pots with ornamental trees and miniature temples. Closer to the lake are two vegetable patches, one containing cabbage and the other several boxes of styrofoam containing different kinds of herbs, for example, chive. On the lake's banks, banana trees rise into the sky. The garden is taken care of by elderly women, who are members of the communal house. They cultivate fresh produce for the communal house's holidays. For example, on the occasion of the first and fifteenth of the lunar month it is customary for the worshippers to receive a small bag with banana and sticky rice after having prayed and donated to the communal houses. Accordingly, the community is fed with the products of the communal house's garden. A man who regularly comes to the space of the communal house to fish explains "This is the garden of the communal house. Retired women come here." Asked about whether everyone from the village is allowed to garden, he answers "No. Only those people that have been serving the communal house for a long time come here" (Interview September 2015, translated from Vietnamese). Gardening on land belonging to a sacred institution has become a common practice. Also in the New Urban Area of Linh Đàm, in which a village structure including the communal house still exists, residents produce cabbage and morning glory on the land belonging to the communal house. Often, communal houses and pagodas occupy large stretches of land that are not allowed to be used for construction. The interviewed gardeners on sacred ground repeatedly answered that they gardened there because it was dất chung (communal land). In effect, conversations with historians revealed that former village statutes (buóng $u^{\prime} o^{\prime} c$ ) were still intact today, guaranteeing villagers the right to exploit common land (Expert interviews with Historians September, October 2015).

Consequently, belonging to a particular community of practice appears to be a necessary prerequisite for cultivating and harvesting the land. Membership to the former cooperative, the communal house or the pagoda community defines the right of access and participation. 


\section{Gardening: Transgressing the Boundaries between Private and Public}

Urban gardening activities in Hanoi point to the permeability and flexibility of the local conceptions of private and public.

First, the case studies show that sidewalks and fallow urban land in New Urban Areas are appropriated by residents to cultivate vegetables and herbs for their own consumption. This finding is in line with previous studies on the usage of public spaces for private economic activities. Similarly, members of a former cooperative and/or sacred institution garden on communal land belonging to the Buddhist pagoda and the communal houses. The members of these communities of practice garden primarily for private consumption. However, the fresh produce cultivated on communal land is used for ritual purposes, too. On festival days and sacred holidays the produce from Yên Phụ communal house's garden is fed back to the community.

Second, adhering to the historical continuity of home gardens in Vietnam, the chapter identified a semantic shift in the practice of gardening in the light of food anxiety. This shift is represented in the functional transformation of home gardens from aesthetics to utility, in which ornamental trees and holy stones are increasingly being replaced by boxes of vegetables and herbs that are perceived as safe and clean as compared to the produce offered at the market.

\section{Rural Practices in Urban Space}

When cultivating vegetables in the city, urbanites literally adopt rural practices. Other than in many cities of the Global North in which the cultivation of vegetables on fallow urban land is commonly referred to as "urban gardening", the Vietnamese gardeners would stick to the term trồng rau (growing vegetables), which is based in agriculture.

Furthermore, the interviewed gardeners often referred to their rural past when asked about their gardening skills. Many stressed that they had acquired the skills and knowledge for the cultivation of herbs and vegetables in the countryside. Thirty-six-year-old Lan Anh explains "I assisted 
my grandmother gardening when I was a child. Therefore I acquired some basic skills. In addition, I retrieve information from the internet before I start cultivating a particular kind of vegetable" (Interview January 2015). Consequently, it is through the training and apprenticeship back home in the countryside that they acquired their gardening skills. Yet, as the quotation reveals, they complement this embodied knowledge with "global" knowledge distributed through digital networks, such as social networking sites and blogs (Interviews October 2015). Such complementary adoption of different forms of knowledge actually indicates rural migrants' "urban insinuation", that is, their "transition from ruralites to urbanites" (Nguyen Tuan Anh et al. 2012, pp. 3, 6). That said, the reference to the rural is, in a general sense, a crucial marker of identity politics in Vietnam. Rural-urban migration to Hanoi dates back to the medieval ages, when artisans and craftsmen from the Red River Delta migrated to Hanoi, establishing the guild area that is known today as the 36 Streets or the Ancient Quarter. What is more, the early years of state socialism in Northern Vietnam saw a wave of migration from the countryside to the city. As independence was in fact won from the countryside, revolutionary cadres from rural areas were encouraged to move to the city. ${ }^{10} \mathrm{~A}$ further migration wave was introduced through economic liberalization as well as the relaxation of the household registration system, which had previously restricted migration within the country (Nguyen Tuan Anh et al. 2012). In search for higher income opportunities, many people from rural areas moved to the city. Accordingly, most urban dwellers still have rural ties. These connections to kin in the countryside are reevaluated in the urbanites' search for clean and safe vegetables.

\section{Rural-Urban Supply Chains}

In order to ensure food safety, urbanites might also draw on their social relations in the countryside. The sending of remittances by family members from the city to the countryside is a common practice in Vietnam (Earl 2014, p. 197). In the light of growing distrust towards obscured production networks, the sending of food supplies from rural areas to the city has gained in importance, too. Interviewees report that they receive 
boxes of fresh vegetables and meat (pork and beef) from their relatives back home in rural areas.

For example, Trung, a father of two, receives a box each month with fresh seafood, such as shrimps and crabs, as well as some vegetables from his family residing in Hạ Long Bay in Quảng Ninh Province. His family sends him the box of fresh food supply by car, while others reported that the goods were sent to them via the diverse bus lines operating throughout the country. Since many people residing in Hanoi regularly visit their places of origin (vî̀ quê) in the countryside on occasions such as weddings, anniversaries of deaths and particularly the Vietnamese lunar New Year, they bring vegetables from their rural places upon returning to Hanoi. For example, Duy comes from a rural area of Vĩnh Phúc Province, located $40 \mathrm{~km}$ outside the city. When he returns home to visit his parents, he brings herbs and vegetables for his friends with small children in Hanoi. While Duy acts as an intermediary of perceived safe produce for his friends, Anh is on the receiving end of such a rural-urban food supply. The father of two reported that he would mainly buy the fresh produce from his relatives and friends, or from friends' relatives. The two examples of Duy and Anh point to the relevance of trust in the supplier-consumer relationship (see Figuié et al., this volume). Urbanites like Trung and Anh actually embed their food supply into trust-based relationships drawing on their social ties to the countryside. They receive the fresh produce either directly from family members or friends, or through middlemen like Duy, who have relatives residing in the countryside. Wertheim-Heck and Spargaaren (2016, p. 659) make similar observations, when identifying "kinship shopping" as a way to ensure food safety. According to them, this strategy builds on the trust in a relative's good intentions, as well as on the belief that producers in rural areas have the necessary knowledge to produce safe vegetables.

The prevailing idea that people from rural areas know how to cultivate safe produce is further illustrated by the case of Thảo.

Thảo, a young Hanoian woman, reports that her mother has, for years, been buying from one particular street vendor who delivered the goods right to their doorstep. The vendor maintained that the vegetables were fresh, coming directly from her village. Thảo told her mother that the vegetables did not come from the countryside but from the urban Long 
Biên Island in the Red River or were even imported from China. Nonetheless, her mother kept on buying from the street vendor. The mother insisted that the vendor would not dare to cheat on the origin of her produce since she knew the trader well. Through the daily interaction with the vendor and the ability to touch and smell the fresh produce, she established a relationship of trust. The case illustrates how "fresh", "clean" and "safe" have come to connote the products' rural origin. In order to be fresh and safe, vegetables are considered to have to come directly from rural areas, or more precisely the village, and not peri-urban areas such as Long Biên Island. Yet this longing for the produce's rural origin does not withstand the real flow of agricultural commodity chains, since over twothirds of vegetables consumed in Vietnam's capital originate from Hanoi's peri-urban region. The remainder is imported from Đà Lạ in the Southern part of the central highlands or China (Gerber et al. 2014). Interviewees frequently reported that they purchased vegetables, herbs and fruits for their own consumption directly from the countryside. For example, Nhiên, a 38-year-old teacher, buys vegetables in her home province of Thái Nguyên or when she visits the countryside for business. Wertheim-Heck and Spaargaren (2016, p. 659) refer to this form of consumption as "farmer shopping". In their account it is the label "local farmer produce" that is regarded a qualifier of food safety. However, this qualifier is solely based on trust. Consumers have neither visited the actual sites of production, nor do they have any information on the methods of agricultural production and the flow of commodity chains.

In sum, consumers draw on personal trust-based relationships and the rural origin to ensure food safety. They do so when attaining produce through kinship shopping, farmer shopping or when purchasing at local markets. However, the end consumers themselves seem to have little knowledge about the actual production sites, having no means to verify the methods of production except for the reports of those from whom they receive their supplies. Overall, respondents considered the rural as a signifier of freshness and safety. This image of the rural is socially constructed in opposition to the city that is often associated with pollution, alienation and disorder (Drummond 2003; Fuhrmann 2017; Kurfürst 2012a; Labbé 2016). 


\section{Reassessing Images of the Rural and the Urban in Vietnam}

Although spatial distinctions between the city and the countryside increasingly seem to dissolve, with more and more people from rural areas moving to the city and urbanites building weekend villas in the countryside, binaries of the rural and the urban continue to inform the way people imagine (urban) space (Gillen 2016; Harms 2011a). Actors designate spaces and practices as either rural or urban, thence (re)producing the binaries in their social interactions. In other words, they continuously draw on the binary categories of the rural and the urban to make sense of their life worlds (Habermas 1995).

According to Harms (2011a), the binaries of the city and the countryside are charged with symbolic meanings. A closer look at the discursive practices constituting this spatial dichotomy reveals that the rural and the urban are actually ascribed with quite ambivalent meanings. On the one hand, the city is considered both a signifier of modernization (biẹn dai) and civilization (vă minh). On the other hand, the city is perceived as a place of environmental pollution and moral corruption. In contrast, the countryside is imagined as a place of tradition, with intact social ties and close contact to nature. But at the same time, the countryside is also regarded a place of backwardness that requires guidance and development from the centre (Drummond 2003, p. 163; Fuhrmann 2017, p. 144; Harms 2011b, pp. 457-458). ${ }^{11}$ In the national narrative, rural life is presented as the cradle of Vietnamese culture, mediating an image of the rural as the place of both a functioning collective and an undamaged nature. In her study of environmental change in Vietnam, Fuhrmann shows that the countryside is associated with a clean environment and a beautiful landscape full of fresh air and green trees. Furthermore, rural people are considered to be in close contact to nature as they regularly interact with nature through plantation and harvest (Fuhrmann 2017, pp. 145-146). This connection to nature in particular, is important to a reading of urbanites' striving for safe and clean produce. According to Fuhrmann (2017, p. 141) the rural is associated with "effortless access to fresh food". Consequently, the countryside is regarded as the purveyor of safe foods. 
Finally, the rural does not so much refer to a specific geographical location, but appears rather to be an imagined space accompanied by a set of specific symbols (Fuhrmann 2017; Gillen 2016; Harms 2011a). The symbols associated with the rural, such as freshness, cleanliness and safety also seem to inform urbanites' consumption decisions in the light of increasing food anxiety. The receiving of boxes of fresh produce from the countryside or local farmer shopping appear to be based on this very idea of the rural, as well as on social bonds to the countryside. As a consequence, bearing the label "rural" sets vegetables apart from other fresh produce, not indexed as such and sold at urban markets, and ascribes them with a different value. However, as already pointed out, the indexicality of the rural does not necessarily mean that the fresh produce meets national or global standards of food safety, but is a valuation based on local perceptions of fresh and clean food.

According to Ehlert and Voßemer (2015, p. 20), actors draw on different forms of knowledge when evaluating the freshness and safety of the produce they consume, such as rational information on food and emic perceptions of freshness and food quality.

\section{Conclusion}

This chapter examined the production sites of clean and safe vegetables, looking at the physical spaces of urban gardening and the practices in situ, as well as at the discursive and consumptive practices constituting rural space. In fact, the chapter focused on the recombination of the dimensions of the rural and the urban within the city of Hanoi.

The case studies presented in this chapter point to the persistence of the socially constructed — though often ambivalent-binary concepts of the rural and the urban. Empirically, the two dimensions are important since social actors apply them to make sense of their lifeworld. As Harms (2011a, p. 84) put it:

Objectively speaking, these categories and associations of rural and urban cannot be physically located on the landscape in any fixed manner. Yet people continue to reproduce them as if they were utterly real, tangible, seemingly material truths. 
Conceptions of the urban and the rural inform what people consider clean and safe vegetables, too. Actually most of the vegetables consumed in Hanoi are produced in the peri-urban region. However, indexing vegetables as rural, as well as receiving vegetables through social networks in the countryside qualify them as safe foods. Additionally, the presented narratives of the countryside in Vietnam and the individual biographies of migration point to the relevance of the rural for identity politics and the feeling of belonging. In fact, those who receive vegetable boxes are only able to do so because they have strong social ties to their rural hometowns. The feeling of belonging is furthermore expressed in urban gardeners' responses of how they acquired their gardening skills, with many explaining that they were able to cultivate their own produce because they grew up in the countryside. Hoa, a home gardener, even says "Truth be told, urbanites lack [gardening] experience" (Interview October 2015, translated from Vietnamese). In sum, urban gardeners combine their skills acquired through apprenticeship back home, with knowledge retrieved from the internet. Consequently, members of the urban community of practice adapt rural practices to the urban-built environment, generating and distributing knowledge through diverse information artefacts. In sum, the boundaries between rural and urban areas are actually blurred and flexible, as they are continuously negotiated through the exchange of commodities, knowledge, people and practices between the two. As Krause (2013, p. 237) affirms "Livelihoods rarely work in sync with the physical properties of places but remain connected to them in complex ways."

Likewise, the urban is characterized by the constant reworking of private and public spaces. In the private space of the home, spaces originally dedicated to spirits, geomancy and aesthetics are turned into spaces of food production. Vegetable boxes placed on the outer extension of the space of worship increasingly replace holy plants, stones and water ponds. What is more, land belonging to sacred institutions, such as the communal house or pagoda, is used for both private and collective consumption, with access being determined by membership to a particular community of practice, for example, the communal house, Buddhist pagoda or former cooperative. 
By using the few open spaces in the city for gardening, citizens actively shape the urban environment, thereby executing their right to the city. They employ what the city offers, such as waste land, waste products in the form of Styrofoam boxes, water bottles or milk packages, to grow vegetables and herbs. In this regard, the city that is otherwise a place associated with environmental pollution can become a place of sustainability, too. Accordingly, the presented urban gardening practices are not actually so different from the manifestations of urban gardening observed in the cities of the Global North. Overall, the presented cases are an expression of citizens' lack of trust in anonymous commodity chains and food supply systems.

\section{Notes}

1. The socialist state propagates the development of modern and civilized cities. The policies linked to this modernization discourse frequently aim at eradicating mobile vendors from the urban landscape in order to establish urban order (trât tư dô thi) (Kurfürst 2012a; Schwenkel 2012).

2. The municipality of Andernach in Germany introduced the project of the "eatable city". For further information see: http://www.andernach. de/de/leben_in_andernach/essbare_stadt.html

3. Bendt et al. (2013) identify Prinzessinnengärten as a public-access community garden which is open to anyone and collectively managed. Prinzessinnengärten was founded in 2009 on a land lot in Berlin's Kreuzberg District, the land rented from the state of Berlin.

4. In her monograph Vietnam's New Middle-Class, Catherine Earl (2014) identifies the accumulation of cultural capital, and thence education and employment, as crucial to the achievement of middle-class status. Moreover, she shows that "conspicuous consumption" (Veblen 1899), particularly indoor-leisure activities, are a marker of class distinction.

5. Through readjustment, the surrounding provinces of Hà Tây, Vĩnh Phúc, Hưng Yên, Bắc Ninh, Hải Dương, Hà Nam und Hòa Bình that used to constitute the capital's hinterland were integrated into the Hanoi Capital Region. Today Bắc Từ Liêm is a part of Câu Giầy District.

6. The fourteenth-century Buddhist monk Tuệ Tĩnh, author of "Nam Dược Thần Hiệu", which is the first known script on Vietnamese medicine, explained the value of Southern medicine to the Vietnamese by 
pointing out the compatibility of medicine derived from the local flora and fauna with Vietnamese bodies (Wahlberg 2014, p. 48). Indeed, Wahlberg (2012b, p. 157) argues that "traditional medicine" is a very recent invention as it is the outcome of a process of institutionalization of health care for all conducted by the socialist state. In this regard, the production of herbal medicine at home was also a cheap and effective way to grant basic health care to all.

7. Xưong sông is used to make spices or to cook soup. It is also served in combination with raw fish.

8. The so-called happy family campaign, launched in 1994, was a major tool of birth control, ascribing the reproductive responsibility to women, rather than men (Bélanger and Barbieri 2009).

9. Kerkvliet (1993, p. 11) reports that since the practice of cooperatives began, 5 per cent of arable land was reserved for private use. Since households were allowed to keep the harvest for themselves, many concentrated their efforts more on the cultivation of their private land plots than on the collective. In the North, the encroachment of private households onto collective land became a common strategy to extend private land plots.

10. As Lentz (2011, p. 564) explains, the revolution was won by the landless rural people who were exploited by landlords. Accordingly, the national founding myth of the socialist state is based on the revolutionary power of the countryside.

11. On the common perception of highlanders as backward and primitive see Salemink (2018).

\section{References}

Adams, David, and Michael Hardman. 2014. "Observing guerrillas in the wild: Reinterpreting practices of urban guerrilla gardening.” Urban Studies 51, no. 6: 1103-1119.

Anh Dung Ta, and Manfredo Manfredini. 2017. "Mobilized Territories in More-Than-Relational Public Spaces. Sidewalk Territories of Resistance in Hanoi, Vietnam." Conference Paper. 10th IFOU—International Forum on Urbanism Conference Hong Kong, December 14-16, 2017.

Anon. 2001. A Selection of Fundamental Laws of Vietnam. Latest Legislation. Hanoi: The Gioi. 
Bakker, Nico, Marielle Dubbeling, Sabine Guendel, Ulrich Sabel-Koschella, and Henk de Zeeuw. 2000. Growing Cities, Growing Food, Urban Agriculture on the Policy Agenda. DSE.

Bélanger, Danièle, and Magali Barbieri (2009). "Introduction. State, Families and the Making of Transitions in Vietnam." In Reconfiguring families in contemporary Vietnam, edited by Danièle Bélanger and Magali Barbieri, 1-46. Stanford University Press.

Bendt, Pim, Stephan Barthel, and Johan Colding. 2013. "Civic greening and environmental learning in public-access community gardens in Berlin." Landscape and Urban Planning 109, no. 1: 18-30.

Certomà, Chiara. 2011. "Critical urban gardening as a post-environmentalist practice.” Local Environment 16, no. 10: 977-987.

Certomà, Chiara, and Chiara Tornaghi. 2015. "Political gardening. Transforming cities and political agency." Local Environment 20, no. 10: 1123-1131.

Dannenberg, Peter, and Alexander Follmann. 2015. "Ringen um Grün in der Stadt." Standort 39, no. 2-3: 94-100.

Drummond, Lisa. 2000. "Street scenes: practices of public and private space in urban Vietnam." Urban Studies 37, no. 12: 2377-2391.

Drummond, Lisa 2003. "Popular television and images of urban life." In Consuming urban culture in contemporary Vietnam, edited by Lisa Drummond and Mandy Thomas, 155-169. London: Routledge Curzon.

Earl, Catherine. 2014. Vietnam's new middle classes: Gender, career, city. Copenhagen: Nias Press.

Ehlert, Judith, and Christiane Voßemer. 2015. "Food sovereignty and conceptualization of agency: A methodological discussion.” Austrian Journal of SouthEast Asian Studies 8, no. 1:7-26.

Evers, Anna, and Nicole L. Hodgson. 2011. "Food choices and local food access among Perth's community gardeners." Local Environment 16, no. 6: 585-602.

Firth, Chris, Damian Maye, and David Pearson. 2011. "Developing 'community' in community gardens." Local Environment 16, no. 6: 555-568.

Flores, Heather. 2006. Food not Lawns: How to Turn Your Garden and Neighbourhood into a Community. Chelsea Green: White River Junction.

Follmann, Alexander, and Valérie Viehoff. 2015. "A green garden on red clay. Creating a new urban common as a form of political gardening in Cologne, Germany." Local Environment 20, no. 10: 1148-1174.

Fuhrmann, Eva. 2017. Perceptions of Change in Vietnam. Human Environmental Values in a Peri-urban Area of Southeast Vietnam. Berlin: Regiospectra. 
Gerber, Jonathan, Sarah Turner, and Lynne B. Milgram. 2014. "Food Provisioning and Wholesale Agricultural Commodity Chains in Northern Vietnam." Human Organization 73, no. 1: 50-61.

Gillen, Jamie. 2016. "Bringing the countryside to the city: Practices and imaginations of the rural in Ho Chi Minh City, Vietnam." Urban Studies 53, no. 2: 324-337.

Habermas, Jürgen. 1995. Theorie Kommunikativen Handelns. Frankfurt a. M.: Suhrkamp.

Harms, Erik. 2011a. Saigon's edge. On the margins of Ho Chi Minh City. Minneapolis: University of Minnesota.

Harms, Erik. 2011b. "Material symbolism on Saigon's edge: Symbolic transformation of Ho Chi Minh City's periurban zones." Pacific Affairs 84, no. 3: 455-473.

Harvey, David. 2012. Rebel Cities. London: Verso Book.

Kerkvliet, Benedict. 1993. State-village relations in Vietnam. Contested cooperatives and collectivization. Working paper Centre of Southeast Asian Studies, No. 85. Clayton: Monash University.

Koh, David. 2006. Wards of Hanoi. Singapore: ISEAS.

Krause, Monika. 2013. "The Ruralization of the World." Public Culture 25, no. 2 70: 233-248.

Kurfürst, Sandra. 2012a. Redefining Public Space in Hanoi. Places, Practices and Meaning. Zürich: LIT.

Kurfürst, Sandra. 2012b. "Informality as a strategy: Street traders facing constant insecurity." In Urban Informalities: Reflections on the Formal and Informal, edited by Colin McFarlane and Michael Waibel, 89-111. Farnham, Surrey: Ashgate.

Labbé, Danielle. 2016. "Critical reflections on land appropriation and alternative urbanization trajectories in periurban Vietnam." Cities 53: 150-155.

Lave, Jean, and Etienne Wenger. 1991: Situated Learning. Legitimate Peripheral Participation. Cambridge: Cambridge University Press.

Le Huu Viet, and Tra Giang. 2014. "Thuê 'kỹ sư osi' chăm sóc rau sạch tại gia." Accessed March 28, 2014, http://www.tienphong.vn/kinh-te/thue-ky-suosin-cham-soc-rau-sach-tai-gia-670939.tpo.

Leaf, Michael. 2002. "A tale of two villages. Globalization and Peri-Urban Change in China and Vietnam." Cities 19, no. 1: 23-13.

Leaf, Michael, and Students of Plan 545. 1999. "Urbanization on the periphery: a Hanoi case study.” Asian Urban Research Network Working Paper Series, No. 24, UBC Centre for Human Settlements, Vancouver. 
Lefebvre, Henri. 1991. The Production of Space. Oxford: Blackwell.

Lentz, Christian. 2011. "Mobilization and State Formation on a Frontier of Vietnam." In: Journal of Peasant Studies 38, no. 3: 559-586.

Marr, David. 2004. "A brief history of local government in Vietnam.” In Beyond

Hanoi. Local Government in Vietnam, edited by Benedict Kerkvliet and David Marr, 28-55. Copenhagen: NIAS.

Ngome, Ivo, and Dick Foeken. 2012. “'My garden is a great help': gender and urban gardening in Buea, Cameroon.” GeoJournal 77, no. 1: 103-118.

Nguyen Khac Tung. 1993. "The village: Settlement of Peasants in Northern Vietnam." In The traditional village in Vietnam, edited by Phan Huy Le, 7-43. Hanoi: The Gioi Publishers.

Nguyen Tu Chi. 1993. "The traditional Viet village in Bac Bo: Its organizational structure and problems." In The traditional village in Vietnam, edited by Phan Huy Le, 44-62. Hanoi: The Gioi Publishers.

Nguyen Tuan Anh, Jonathan Rigg, Luong Thi Thu Huong, and Dinh Thi Dieu. 2012. "Becoming and being urban in Hanoi. Rural-urban migration and relations in Viet Nam." Journal of Peasant Studies 39, no. 5: 1103-1131.

Nguyen Van Suu, 2004. "The politics of land: Inequality in Land Access and Local Conflicts in the Red River Delta since Decollectivization.” In Social inequality in Vietnam and the challenges to reform, edited by Philip Taylor, 270-296. Singapore: ISEAS.

Parnell, Susan, and Jennifer Robinson. 2013. "(Re)theorizing Cities from the Global South: Looking Beyond Neoliberalism.” Urban Geography 33, no. 4: 593-617.

Phan Huy Le. 2006. "Research on the Vietnamese Village: Assessment and Perspectives." In Viet Nam. Borderless histories, edited by Tran Nhung Tuyet and Anthony Reid, 23-41. Madison: University of Wisconsin.

Robinson, Jenny. 2006. Ordinary cities. Between modernity and development. London, New York: Routledge.

Roy, Ananya. 2014. "Worlding the South: towards a post-colonial urban theory." In The Routledge handbook on cities of the Global South, edited by Susan Parnell and Sophie Oldfield, 9-20. London: Routledge.

Salemink, Oscar. 2018. "The Regional Centrality of Vietnam's Central Highlands." In Oxford Research Encyclopedia of Asian History, edited by David Ludden, 1-30: Oxford University Press.

Schmelzkopf, Karen. 2002. "Incommensurability, land use, and the right to space: community gardens in New York City.” Urban Geography 23, no. 4: $323-343$. 
Schwenkel, Christina. 2012. "Civilizing the City. Socialist Ruins and Urban Renewal in Central Vietnam." Positions 20, no. 2: 437-470.

Simiyu, Romborah R., and Dick Foeken. 2014. "Urban crop production and poverty alleviation in Eldoret, Kenya: Implications for policy and gender planning." Urban Studies 51, no. 12: 2613-2628.

Staeheli, Lynn, Don Mitchell, and Kristina Gibson. 2002. "Conflicting rights to the city in New York's community gardens.” GeoJournal 58, no. 2/3: 197-205.

Thanh Nien News. 2016. "1.2 million Vietnamese move to the city every year." Accessed September 13, 2017, www.thanhniennews.com/society/12-million-vietnamese-move-to-cities-every-year-report-64140.html.

Thomas, Mandy. 2002. "Out of Control: Emergent Cultural Landscapes and Political Change in Urban Vietnam." Urban Studies, 39, no. 9: 1611-1624. To Xuan Phuc. 2012. "When the Đai Gia (Urban Rich) go to the Countryside: Impacts of the Urban-Fuelled Rural Land Market in the Uplands." In The Reinvention of Distinction. Modernity and the Middle Class in Urban Vietnam, edited by Van Nguyen-Marshall, Lisa Drummond and Danièle Bélanger, 143-154. ARI: Springer Asia Series.

UN-Habitat. 2012. State of the World's Cities, 2012-2013. Nairobi: UN-Habitat.

Veblen, Thorstein. 1899. The theory of the leisure class. New York: A. M. Kelley. Wahlberg, Ayo. 2012a. "A revolutionary movement to bring traditional medicine back to the grassroots level: On the biopolitization of herbal medicine in Vietnam." In Global Movements, Local Concerns: Medicine and Health in Southeast Asia, edited by Laurence Monnais-Rousselot and Harold J. Cook, 207-225. Singapore: NUS Press.

Wahlberg, Ayo. 2012b. "Family Secrets and the Industrialisation of Herbal Medicine in Postcolonial Vietnam." In Southern medicine for Southern people. Vietnamese medicine in the making, edited by Laurence MonnaisRousselot, Claudia Michele Thompson und Ayo Wahlberg, 153-178. Cambridge Scholars Publishing.

Wahlberg, Ayo. 2014. "Herbs, Laboratories, and Revolution: On the Making of a National Medicine in Vietnam." East Asian Science, Technology and Society 8 , no. $1: 43-56$.

Wertheim-Heck, Sigrid, and Geert Spaargaren. 2016. "Shifting configurations of shopping practices and food safety dynamics in Hanoi, Vietnam: a historical analysis." Agri Hum Values 33:655-671. 
Witheridge, Jennifer and Nina J. Morris. 2016. "An analysis of the effect of public policy on community garden organisations in Edinburgh." Local Environment 21, no. 2: 202-218.

World Bank. 2018. "Urban population.” Accessed January 25, 2018. https:// data.worldbank.org/indicator/SP.URB.TOTL.IN.ZS

Open Access This chapter is licensed under the terms of the Creative Commons Attribution 4.0 International License (http://creativecommons.org/licenses/ by/4.0/), which permits use, sharing, adaptation, distribution and reproduction in any medium or format, as long as you give appropriate credit to the original author(s) and the source, provide a link to the Creative Commons licence and indicate if changes were made.

The images or other third party material in this chapter are included in the chapter's Creative Commons licence, unless indicated otherwise in a credit line to the material. If material is not included in the chapter's Creative Commons licence and your intended use is not permitted by statutory regulation or exceeds the permitted use, you will need to obtain permission directly from the copyright holder.

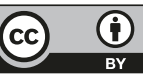

